\title{
Pemanfaatan Sensor Suara sebagai Fitur On/Off Switch pada Engine Starter dan Power Tailgate Kendaraan
}

\author{
Ian Hardianto Siahaan ${ }^{*}$, Kresna Vincent ${ }^{2}$, Teng Sutrisno ${ }^{3}$, Ninuk Jonoadjii \\ 1,2,3,4 Program Studi Teknik Mesin, Fakultas Teknologi Industri, Universitas Kristen Petra \\ Jl. Siwalankerto 121-131, Surabaya 60236, Indonesia \\ * Penulis korespondensi; E-mail: ian@petra.ac.id
}

\begin{abstract}
ABSTRAK
Fitur otomotif mengalami perkembangan pesat secara berkelanjutan sebagai dampak perkembangan revolusi industri 4.0, khususnya dalam hal memudahkan pengoperasian fitur sebagai penunjang keselamatan maupun kenyamanan berkendara. Fitur yang dirancang dengan cara mengintegrasikan sensor suara untuk menyalakan dan mematikan engine starter dengan memanfaatkan car starter motor bawaan dari kendaraan itu sendiri. Selain itu ditambahkan juga fitur membuka dan menutup bagasi kendaraan sehingga bisa berfungsi secara otomatis. Operasional on/off switch untuk engine starter dan power tailgate menggunakan media internet eWeLink dan google home sebagai penghubung sensor suara dengan switch dan aktuator power tailgate secara wireless melalui perintah yang telah diprogramkan pada perangkat. Pada penelitian ini berhasil menyalakan atau mematikan engine starter berkisar 1 detik sedangkan untuk membuka dan menutup berkisar 1 menit. Namun, berdasarkan hasil diskusi pada pengujian bahwa waktu untuk membuka atau menutup power tailgate ini masih tergolong lama hal ini disebabkan pada saat eksisting pemilihan spesifikasi motor aktuator yang ada di pasaran belum mendapatkan requirement yang memadai meskipun dari sisi fungsional telah bekerja dengan baik.
\end{abstract}

Kata kunci: Engine starter, power tailgate, sensor suara, switch, google home.

\begin{abstract}
Automotive features are experiencing rapid development on an ongoing basis as a result of the development of the industrial revolution 4.0, especially to facilitate the operation of features to support safety and driving comfort. A feature designed by integrating a sound sensor to promote on and off the engine starter by utilizing the car starter motor built into the vehicle. In addition, the feature of opening and closing the power tailgate is also added so that it can work automatically. Operation of on /off switch for engine starter and power tailgate use internet media eWeLink and google home as a connecting sound sensor with switches and power tailgate actuators wirelessly through commands programmed on the device. In this study, the engine starter was successful or turned off in about 1 second to open and close for 1 minute. However, based on the results of the discussion on the test that the time to open or close the power tailgate is still relatively long, this is because at the time of the existing selection of actuator motor specifications on the market, it has not obtained adequate results even though from a functional side it has worked well.
\end{abstract}

Keywords: Engine starter, power tailgate, sound sensor, switch, google home.

\section{PENDAHULUAN}

Umumnya, kendaraan selalu dilengkapi dengan berbagai sensor yang digunakan untuk mendukung operasional fitur yang ada didalamnya. Namun, penggunaan beberapa sensor tidak selalu diimplementasikan pada semua kendaraan. Awalnya, ada beberapa pertimbangan pabrikan ketika mendesain fitur tersebut. Faktor yang paling dominan adalah faktor segmentasi pasar dan nilai ekonomis dari kendaraan tersebut di market place.
Revolusi industri 4.0 yang semakin gencar mendorong pabrikan otomotif mulai melakukan improvisasi fitur kendaraan menjadi lebih bervariasi dan komplek, khususnya untuk mendukung safety dan kenyamanan berkendara. Pabrikan otomotif dan pengguna kendaraan terlihat mulai berlomba lomba menampilkan kebaharuan teknologinya dengan cara mengimplementasi fitur kendaraan melalui adopsi teknologi sensor yang terupdate sehingga lebih handal, efisen dan efektif tanpa harus terikat dengan faktor ekonomis dan segmentasi pasar. Beberapa 
teknologi sensor yang mulai dipergunakan adalah sensor suara. Sensor suara dikategorikan sebagai pendukung vehicle infotainment systems di dalam kendaraan. Vehicle infotainment systems ini dikendalikan melalui perintah suara dan menjadi semakin umum untuk kendaraan keluaran yang terbaru. Suara merupakan mode komunikasi utama, paling efisien dan paling banyak digunakan di antara manusia [1]. Penerapan teknologi pengenalan suara pada kendaraan membuat kendaraan menjadi lebih pintar layaknya sebagaimana manusia. Sensor suara dalam hal ini sebagai fitur yang menjembatani perangkat yang dirancang sehingga dapat berkomunikasi langsung dengan beberapa aplikasi teknologi pengenalan suara lainnya. Fitur yang diaktifkan dengan suara, tampaknya kini merupakan evolusi alamiah dalam hal kenyamanan dan keselamatan berkendara yang membutuhkan sedikit pembenaran karena akan melindungi pemilik kendaraan sekalipun dengan profil kendaraan yang beragam. Dengan implementasi fitur suara tersebut akan memudahkan ketika melakukan banyak aktivitas sekalipun sedang berkendara di jalan raya. Hal ini membuat fitur kendaraan ini semakin diminati para konsumen disebabkan oleh kemudahan dalam pengoperasiannya yang juga sekaligus dapat mendongkrak nilai jual kendaraan tersebut ketika dijual kembali.

Di sisi lainnya, pencurian mobil merupakan ancaman bagi pemiliknya. Pertimbangan ini menyebabkan pabrikan mengamati perlunya diintegrasikan fitur kendaraan seperti itu untuk menunjang faktor safety dari resiko pencurian kendaraan. Walaupun sekuritas pintar yang tersedia di kendaraan sudah memadai, namun masih tetap masih berisiko dicuri karena kurangnya sistem keamanan yang lebih canggih lagi misalnya dengan pengkodean atau sistem imaging. Fitur yang diusulkan ini memerlukan beberapa desain mekanisme yang benar-benar akan memberikan perlindungan dan keamanan tingkat lanjut untuk mengantisipasi berbagai kasus di lapangan yang mungkin terjadi.

Untuk mengatasi masalah yang telah dijelaskan di atas, maka diusulkan penelitian keselamatan dan kenyamanan berkendara dengan sistem pengenalan suara yaitu menggunakan sensor suara untuk pengoperasian lebih mudah bagi si penggunanya. Meskipun sistem keselamatan aktif dan pasif kendaraan menjadi semakin matang, pengemudian yang aman tetap menjadi aspek utama [2].

Semua sistem pengenalan suara saat ini juga masih kurang dari 100\% akurasinya. Dalam arti kata hanya terkontrol $92 \%$ per kata digunakan dalam percobaan dengan target yang diharapkan 90\%-95\% akurat. Sistem pengenalan suara otomatis dapat didefinisikan sebagai transkripsi bahasa lisan yang independen dan digerakkan oleh komputer menjadi teks yang dapat dibaca secara real time [3].

Ruang lingkup penelitian ini berupaya mengimplementasi fitur pada kendaraan tertentu dulu sebagai model untuk usulan desain dengan cara memanfaatkan sensor suara yang terhubung dengan jaringan internet untuk akses jarak jauh, namun pada kondisi ini jaringan internet dibatasi hanya pada penggunaan fitur ini. Dalam hal ini fokus penelitian ini untuk menyederhanakan aktivitas pengemudi dan penumpang kendaraan, sehingga menjadi sistem yang mudah digunakan dan dikendalikan untuk menyalakan/mematikan engine starter dan membuka/menutup pintu bagasi belakang secara inovatif dan sensitif terutama pada suatu kondisi lingkungan yang tidak bising ketika mengirimkan perintah suara.

\section{METODOLOGI}

Ada beberapa penelitian yang mendukung topik penelitian terkait dengan teknologi pengenalan suara. Menurut I.Alice Joseline dan Mrs.S.Benila, pengenalan suara adalah sebuah teknologi yang dibutuhkan oleh sebuah mesin untuk dapat menginterpretasikan ucapan atau suara manusia. Beberapa pengenal ucapan komersial sekarang ini, bahkan sudah dapat menangani dengan tingkat keakurasian lebih dari $90 \%$. Alat sintesis untuk ucapan ini juga sekarang sudah banyak tersedia, contoh alat tersebut adalah Speech API dan Speech Works dari Microsoft Speechify [4].

Penggunaan suara menjadi alasan tertentu, misalnya dalam menghindari kontak manual secara total. Dengan cara ini, kemampuan untuk mengakses sistem akan semakin konsisten di dalam kendaraan. Selanjutnya, sistem interaktif pengenalan suara dari kendaraan diharapkan memungkinkan pengemudi untuk melakukan sesuatu tanpa dipengaruhi gerakan mata dan tangan selama pengoperasian perangkat yang dipasang di mobil, dengan cara itu memungkinkan untuk melaksanakan tugas lainnya dengan mudah. Selanjutnya, tindakan rumit seperti memutar nomor ponsel biasanya dilarang saat berkendara akan menjadi solusi mudah dengan aplikasi ini[5].

Salah satu aspek yang paling kritis dari pertukaran sinyal adalah menyangkut umpan balik yang diberikan kepada pengguna. Ini mirip dengan asisten google yang berfungsi berdasarkan instruksi si pengguna. Hal ini sangat sederhana sebagai contoh yang dapat digunakan, misalnya dalam memberikan instruksi seperti menekan ikon suara dan berikan perintah pada aplikasinya [6]

Namun, sistem yang dikendalikan suara bukan tanpa batasan, akurasinya dapat menurun di lingkungan yang bising ketika berkendara, seperti: adanya hiburan audio yang menyala, percakapan diantara sesama penumpang, dan kebisingan luar [7]. Pengenalan suara berfungsi sebagai saluran yang mengubah audio digital PCM (Pulse Code Modulation) dari kartu suara menjadi suara yang dapat dikenal. Sistem pengenalan suara ditemukan ternyata masih memiliki tingkat kegagalan 2,5\%. Menggunakan sistem pengenalan suara bukan 
semata-mata untuk masalah keamanan atau tergantung sumber suara tetapi juga dapat digunakan untuk sumber suara independen seperti lalu lintas otomatis maupun sebagai sistem pengawasan untuk manajemen lalu lintas [8]. Konsep pengenalan suara sangat inovatif dan sensitif pada kendaraan dan dalam hal ini dapat dibuat lebih aman menggunakan proses analisis perintah suara. Kerangka pengenalan suara menggunakan kata-kata yang diungkapkan secara verbal sebagai informasi. Informasi ini memungkinkan perangkat untuk membedakan kata yang diucapkan secara tepat sehingga fungsi yang spesifik sekalipun dapat dieksekusi [9]. Teknologi bluetooth atau internet akan bertukar data melalui jarak pendek tetapi merupakan cara yang sangat mutakhir untuk berkomunikasi antara dua perangkat sekaligus, misalnya: mikrokontroler dan smartphone [10].

Berbagai sistem juga telah dikembangkan untuk berinteraksi dengan mesin maupun perangkat kendaraan lainnya, tentunya untuk tujuan keamanan kendaraan. Para peneliti telah mengembangkan berbagai sistem. Sistem ini tentunya harus beroperasi pada suara manusia. Sesegera sistem mendeteksi suara pemilik, maka sistem ini dapat diaktifkan [11]. Kendaraan akan dipasangi wireless switch relay on/off dan aktuator yang dapat membuka dan menutup power tailgate yang terhubung dengan sistem kelistrikan di dalam kendaraan untuk dapat memerintahkan aktuator dan engine starter tanpa harus menekan tombol tombol fisik di dalam kendaraan. Jika semua listrik sudah terpasang, maka akan terhubung ke aplikasi google home dan terhubung ke saklar nirkabel untuk diakses menggunakan perintah suara yang diucapkan.

Setelah mengirimkan perintah suara sebagai input di google home, pengguna harus terlebih dahulu memastikan perintah suara yang disampaikan dapat diterima dengan jelas oleh sensor suara. Jika google home tidak memahami inputan perintah suara yang diberikan, akan terjadi salah tafsir, sehingga fitur tidak dapat melakukan proses. Oleh karena itu, perlu dilakukan evaluasi terhadap perintah ucapan yang diucapkan agar dapat diterima oleh google home sehingga dapat mengakses aktuator berfungsi. Perintah ucapan yang diberikan sebaiknya dirancang secara sederhana dan mudah pelafalannya sehingga tidak memberikan salah tafsir ketika sensor menerima data.

Bagan gambar 1 merupakan blok diagram mekanisme untuk operasional engine starter dalam mendeskripsikan tentang urutan proses kerja untuk menyalakan dan mematikan engine starter dengan input perintah suara yang diterima oleh sensor melalu jaringan nirkabel dan diproses google home dan selanjutnya eWeLink menerima perintah suara sehingga program default dari switch atau saklar menjalankan perintah sehingga dapat mengakses engine starter bekerja.

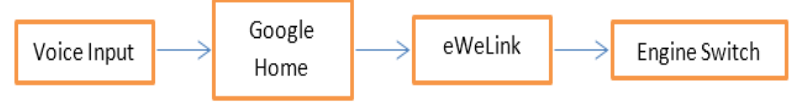

Gambar 1. Blok Diagram Mekanisme untuk Engine Starter

Selanjutnya gambar 2 blok diagram di bawah menjelaskan bagan atau proses untuk membuka dan menutup power tailgate melalui input suara yang berisi perintah-perintah yang telah dipilih dan memasuki program sesuai dengan yang telah dipilih. Setelah itu, suara tersebut akan ditangkap oleh sensor dan dimasukkan serta diproses oleh google home. Setelah proses selesai, eWeLink menerima program default dari sakelar nirkabel yang telah diprogram untuk menjalankan perintah yang akan membuka dan menutup pintu belakang kendaraan. Kemudian aktuator menjalankan proses dimana masing-masing program tersebut membutuhkan jaringan internet agar fiturnya dapat dijalankan menggunakan perintah suara yang dikirimkan.

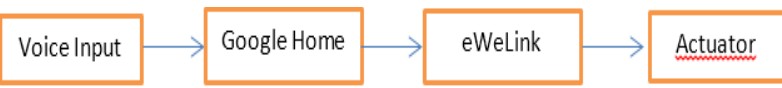

Gambar 2. Blok Diagram Mekanisme Power Tailgate

Secara menyeluruh sistem kelistrikan mekanisme atau wiring diagram fitur tersebut baik untuk engine starter dan power tailgate dapat dilihat berdasarkan gambar 3 pada bagan wiring diagram, berikut.

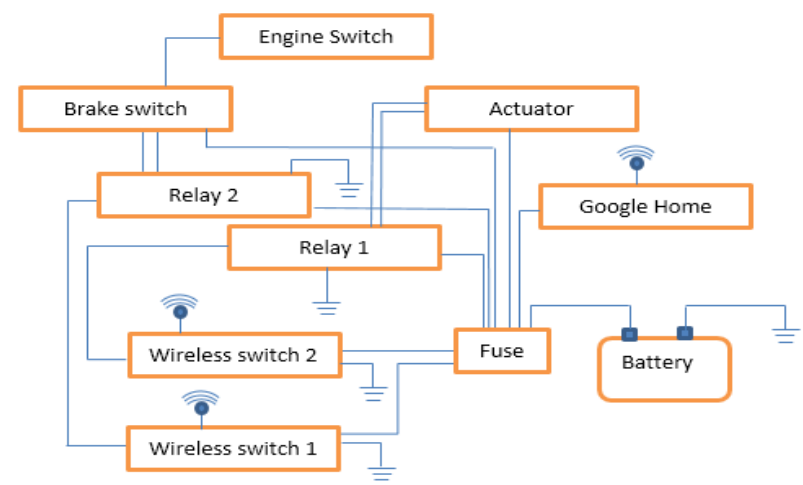

Gambar 3. Rancangan Wiring Diagram Fitur

\section{HASIL DAN PEMBAHASAN}

Jika setiap komponen sudah terpasang dengan benar dan program aplikasi sudah terpasang sesuai dengan mekanisme rancangan, maka yang dilakukan adalah menguji performa engine starter kendaraan dan sistem power tailgate. Pedoman yang digunakan adalah terlebih dahulu melakukan set-up perintah suara pada engine starter apakah sudah menggunakan kata kunci yang tepat untuk diterima oleh sensor dan diolah sehingga dapat mengakses on/off relay pada engine starter. Selanjutnya set-up dilakukan juga dengan perintah suara untuk membuka power tailgate. Pada pengujian awal perintah yang disampaikan gagal menjalankan akses karena 
kata kata perintah yang digunakan terlalu panjang sehingga sukar dideteksi oleh sensor suara untuk dapat diproses di google home dan eWeLink yang dalam hal ini gagal untuk menghubungkan ke engine switch maupun ke actuator power tailgate. Pengujian berikutnya akhirnya dilakukan dengan mengubah perintah suara menjadi lebih pendek dengan lingkup pengujian yang tersedia tanpa suara bising atau berisik. Berikut perintah suara yang telah diubah dengan kalimat pendek tersebut.

Tabel 1. Perintah Suara dan Hasil

\begin{tabular}{ll}
\hline Perintah Suara & Hasil \\
\hline Open & Open the luggage \\
Close & Close the luggage \\
Start Engine & Turn on the car starter. \\
Stop Engine & Turn off the car starter. \\
\hline
\end{tabular}

Pada tabel 1, perintah suara dan hasil dalam hal ini mendeskripsikan kelompok perintah suara yang telah dipilih sebagai input untuk melaksanakan perintah sesuai target yang diinginkan. Setiap kali mengucapkan kata perintah di dalam tabel, perangkat sistem akan secara otomatis menjalankan fitur-fitur ini sesuai dengan input suara. Terkadang pengucapan perintah suara tidak akurat karena dibaca secara berbeda oleh google home, yang dapat menyebabkan interpretasi berbeda yang dapat ditangkap sensor. Kemudian, koneksi jaringan internet yang terkadang terputus menyebabkan tidak berfungsi dan tidak dapat dibaca dengan jelas oleh google home. Selain itu, kecepatan aktuator juga relatif lambat karena membutuhkan waktu lama untuk membuka atau menutup power tailgate akibat putaran gigi rendah yang dipilih kurang sesuai saat perancangan karena keterbatasan spesifikasi komponen yang ada di pasaran.

Setelah menguji kinerja sensor suara dengan mengubah perintah suara dengan kata kata yang lebih singkat dan padat serta mampu mengakomodasi hal-hal yang harus dilakukan pada saat melakukan pengujian, akhirnya fitur yang dirancang berhasil menyalakan atau mematikan engine starter dan juga membuka atau menutup power tailgate sebagaimana ditunjukkan pada gambar 4 berikut ini.

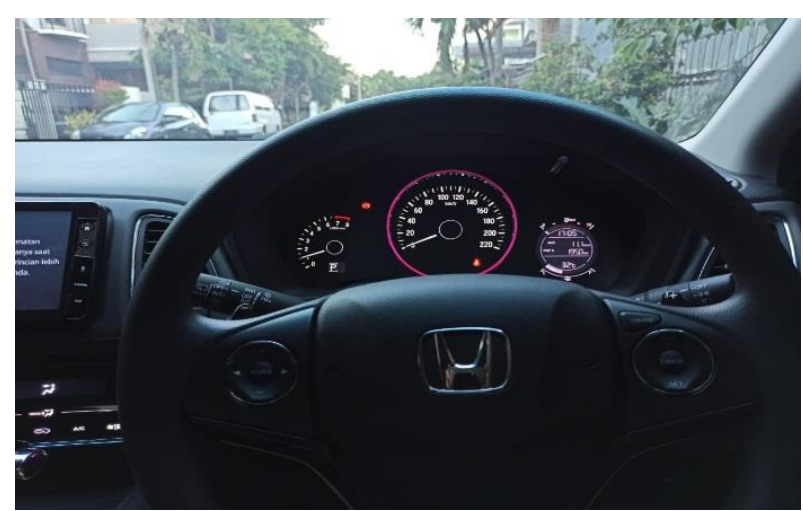

Gambar 4. Pengujian Engine Starter
Posisi Penempatan aktuator power tailgate di dalam kendaraan diberikan pada gambar 5 , dalam hal ini aktuator yang dipilih menggunakan aktuator linier sehingga power tailgate dapat diatur pergerakannya naik atau turun secara otomatis sesuai perintah suara.
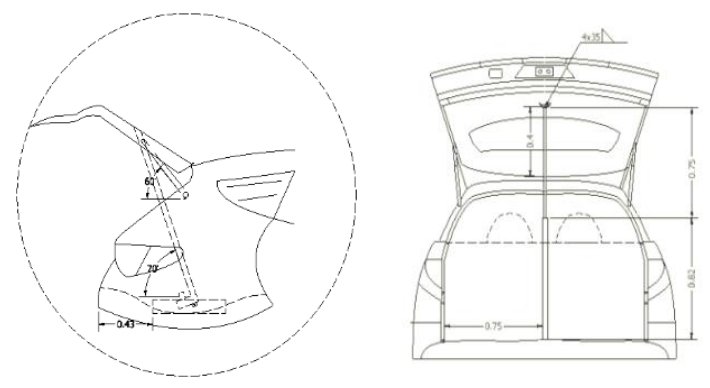

Gambar 5. Posisi Penempatan Aktuator Linier pada Kendaraan Uji

Dengan bantuan software CAD, spesifikasi dari aktuator linier yang digunakan dalam rancangan ditunjukkan pada gambar 6 .
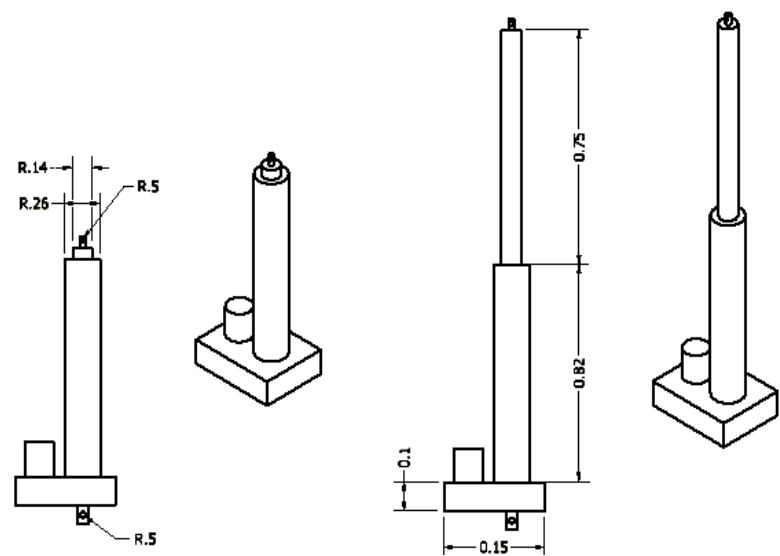

Gambar 6. Dimensi dan Freebody Diagram Aktuator Linier

Selanjutnya, dari gambar 6 di atas dilakukan analisa struktur untuk mengetahui besarnya gaya yang dibutuhkan pada pengujian untuk membuka atau menutup power tailgate sebagaimana diberikan dalam tabel 2.

Tabel 2. Sudut Aktuator vs Gaya Aktuator

\begin{tabular}{lr}
\hline Angle $\left(^{(}\right)$ & $\mathbf{F}_{\text {Act }}(\mathbf{N})$ \\
\hline 140 & 663,639 \\
90 & 344,065 \\
60 & 265,694 \\
45 & 137,193 \\
30 & 17,130 \\
\hline
\end{tabular}

Besarnya $F_{\text {Act }}$ adalah gaya yang dibutuhkan untuk membuka mekanisme power tailgate. Dari hasil analisa tersebut, pemilihan spesifikasi aktuator yang sesuai menjadi sasaran yang penting mengukur kinerja fitur tersebut. 


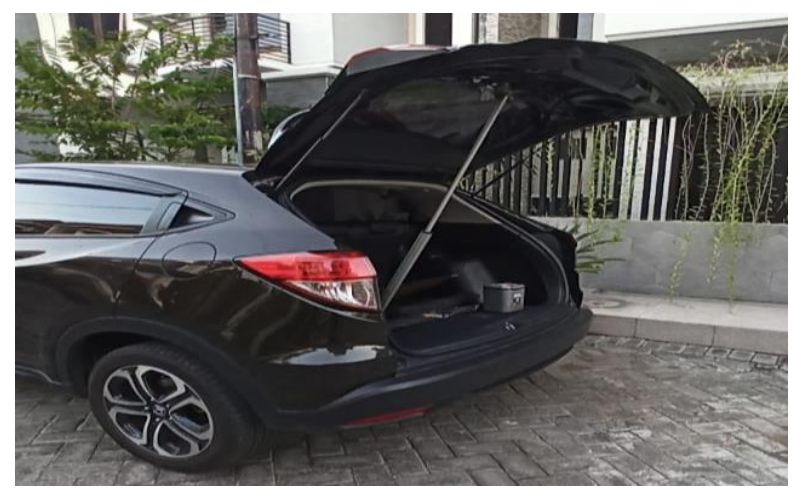

Gambar 7. Posisi Aktuator Maksimum Saat Membuka

Gambar 7 posisi aktuator maksimum menunjukkan bahwa mekanisme aktuator power tailgate menggunakan sensor suara berhasil membuka power tailgate dengan sempurna. Dimana, proses membuka atau menutup mekanisme power tailgate berkisar 1 menit. Durasi ini masih tergolong cukup lama, hal ini kemungkinan disebabkan pada saat pemilihan dinamo yang ada di pasaran belum ditemukan spesifikasi requirement yang memadai. Meskipun durasi membuka dan menutup mekanisme power tailgate masih tergolong cukup lama karena putaran yang dipilih masih tergolong rendah dari harapan, namun hasil pengujian yang dilakukan telah berfungsi dengan baik.

\section{KESIMPULAN}

Masalah yang dibahas dalam artikel ini didasarkan pada hasil dan pembahasan evaluasi pengujian yang menyatakan bahwa desain mekanisme telah berhasil dan berfungsi baik untuk engine starter dan power tailgate. Namun, pada pada saat pengujian pembukaan mekanismenya masih belum sempurna. Ketidaksempurnaan ini disebabkan oleh waktu yang dibutuhkan masih berkisar 1 menit saat membuka atau menutup power tailgate. Pertimbangan ini disebabkan pada pemilihan motor yang masih kurang sesuai meskipun sudah disesuaikan dengan existing motor yang ada di pasaran. Namun sisi lain rancangan untuk engine starter sudah memenuhi dan cukup memadai ketika dinyalakan atau dimatikan karena sudah mencapai kurang lebih 1 detik setelah mengirimkan perintah suara baik dari dalam atau dari luar kendaraan.

Semua fitur telah dapat berfungsi dengan baik pada saat pengujian karena pada pengujian koneksi jaringan internet juga berjalan lancar dan baik tanpa ada kendala berarti. Sedangkan untuk mengantisipasi ketika jaringan internet down atau terputus, fitur ini masih dapat berfungsi selama operasionalnya secara manual ketika mengalami malfunction sistem jaringan. Fitur ini juga dirancang untuk mengantisipasi hal-hal yang mungkin timbul selama pengoperasian, sehingga sebagai safety disiapkan dengan double mode.

\section{DAFTAR PUSTAKA}

[1]. Sawakere, P. A., 2015, "Speech Recognition Techniques," A Review, International Journal of Scientific \& Engineering Research, vol. 6, Issue 8.

[2]. DanNuo, J., Xin, H., JingHan, X., Ling, W., 2019," Design of Intelligent Vehicle Multimedia Human-Computer Interaction System," IOP Conf. Series: Materials Science and Engineering 563.

[3]. Kaur, I., Kaur, N., Ummat, A., Kaur, J., Kaurmer, N., 2016," Automatic Speech Recognition: A Review," IJCST, Vol. 7, Issue 4.

[4]. Joseline, I. A., Benila, S., 2017," Voice Recognition Based Vehicle Manufacturing," International Journal of Engineering Development and Research, Volume 5, Issue 2.

[5]. Loh, C. Y., Boey, K. L., Hong, K. S., 2017, “Speech Recognition Interactive System for Vehicle", International Colloquium on Signal Processing $\&$ its Applications, Penang, Malaysia.

[6]. Veeramani, R., Madhanmohan, R., Prajapati, D., Kumar, A., Kumar, S., 2019," Iot Based Speech Recognition Controlled Car using Arduino," International Journal of Engineering and Advanced Technology (IJEAT), Volume-9 Issue-1.

[7]. Sokol, N., Chen, H. W., Donmez, B., 2017, "Voiced- Controlled in Vehicles Systems: Effects of Voice-Recognition Accuracy in The Presence of Background Noise," Proceedings of the Ninth International Driving Symposium on Human Factors in Driver Assessment, Training and Vehicle Design.

[8]. Astuti, W., Riyandwita, E. B. W., 2016, "Intelligent Automatic Starting Engined Based on Voice Recognition System," IEEE Student Conference on Research and Development (SCOReD).

[9]. Divakar, A, 2019, "Automatic Vehicle Turn Indicator using Speech Recognition," International Journal of Recent Technology and Engineering (IJRTE), ISSN: 2277-3878, Volume-8 Issue3

[10]. Memon, Y. A., 2016, "Speed Recognition System For A Voice Controlled Robot with Real-Time Obstacle Detection and Avoidance," International Journal Of Electrical, Electronics And Data Communication, Volume-4, Issue-9.

[11]. Kakde, N. A., Shinde, A. V., 2016, "Development and Evaluation of Automotive Speech Interfaces, "Useful Information from the Human Factors and the Related Literature," International Journal of Recent Trends in Engineering \& Research, Volume 02, Issue 04. 